\title{
AVALIAÇÃO DA CONTAMINAÇÃO BACTERIANA EM ADESIVOS PARA PRÓTESE TOTAL.
}

\section{Morgana Kelly de Souza Santos ${ }^{1}$; Mário Cezar Silva de Oliveira²; Monique Stefane Cordeiro de Souza ${ }^{3}$}

\author{
1Bolsista PROBIC/Uefs, Graduanda em Odontologia, email: morgakelly@hotmail.com \\ ${ }^{2}$ Orientador, Departamento de Saúde, Universidade Estadual de Feira de Santana, email: mcezar11@gmail.com \\ 33olsista PIBIC/Cnpq, Graduanda em Odontologia, Universidade Estadual de Feira de Santana, email: \\ moni_csouza@hotmail.com
}

Palavras-chave: Prótese Dentária; Adesivos; Microbiologia

\section{INTRODUÇÃO}

Os adesivos são produtos utilizados para promover a fixação entre a prótese total e a mucosa. São compostos geralmente por um polissacarídeo sintético (agente de adesão) além de corantes, antifúngicos e estabilizantes. De acordo com Shay (1991) e Polyzois e colaboradores (2011) o mecanismo de ação se faz por meio da absorção de água que aumenta o volume e a viscosidade do produto, ocupando os espaços que poderiam ficar entre a prótese e o rebordo, melhorando sua adaptação. Os benefícios da utilização dos adesivos seriam: aumentar a habilidade mastigatória, aumentar a estabilidade da prótese e diminuir o acúmulo de alimentos na base da prótese (Adisman 2012; Ozcan et al 2005). Porém, pouco se sabe sobre sua influência na microbiota bucal, seu potencial de citotoxidade e se o uso contínuo pode acelerar a reabsorção óssea alveolar e provocar hiperplasia tecidual em pacientes desdentados totais (Ozcan et al.,2005; Koronis et al., 2012). Portanto, o objetivo desse estudo foi avaliar in vitro a contaminação bacteriana em 03 adesivos para prótese total disponíveis no mercado.

\section{MATERIAIS E MÉTODOS}

Este estudo analisou a contaminação bacteriana através de infusão de três adesivos para prótese disponíveis comercialmente, formulados em creme, pó e tiras: Ultra Corega ${ }^{\circledR}$ creme, Ultra Corega ${ }^{\circledR}$ pó e Ultra Corega ${ }^{\circledR}$ fita adesiva. 0,5 g de cada adesivo foram diluídos a 1:100 em solução de $\mathrm{NaCl}$ e semeados diretamente sobre as superfícies das placas de Petri contendo BHI. As placas foram incubadas em estufa bacteriológica a $37{ }^{\circ} \mathrm{C}$ em condições aeróbias. Unidades formadoras de colônia (UFC) foram contadas após a incubação. As colônias desenvolvidas no meio de cultura foram identificadas por suas características morfológicas em microscopia ótica e a contagem estimada do número de Unidades Formadoras de Colônias (UFC) foi realizada multiplicando-se o número de colônias pelo fator de diluição utilizado. 


\section{RESULTADOS E DISCUSSÃO}

Todas as placas semeadas contendo o Ultra Corega ${ }^{\circledR}$ pó e Ultra Corega ${ }^{\circledR}$ fita adesiva apresentaram crescimento bacteriano no meio de cultura. As placas com adesivos em fita apresentaram esporos aeróbios Gram-positivos e cocos Gram-positivos que cresceram no meio de cultura. No entanto, para as amostras de adesivos em creme diluídas não se observou crescimento bacteriano. Os produtos Ultra Corega ${ }^{\circledR}$ pó e Ultra Corega ${ }^{\circledR}$ fita adesiva apresentaram contaminação bacteriana detectável em meio de cultura o que corrobora com resultados de outros estudos que encontraram fungos e bactérias em amostras de adesivos (Sampaio et al, 2011; Shay et al, 1991). Embora nenhum agente patogénico potencialmente perigoso tenha sido identificado nos adesivos, esse fato deve ser considerado sobretudo na indicação desses produtos para indivíduos imunocomprometidos. O adesivo em forma de creme não apresentou contaminação bacteriana, o que pode estar relacionado à adição de agentes antimicrobianos na sua composição (Duqum,2012; Grasso,2004; Oliveira, 2010; Sampaio ,2011).

\section{CONCLUSÃO}

Apenas os adesivos Ultra Corega ${ }^{\circledR}$ pó e Ultra Corega ${ }^{\circledR}$ fita adesiva apresentaram contaminação bacteriana.

\section{REFERÊNCIAS}

1. SHAY, K. Denture adhesives. Choosing the right powders and pastes. J Am Dent Assoc 1991; 122:70-76.

2. POLYZOIS, G.; LAGOUVARDOS, P., FRANGOU, M., STEFANIOTIS, T. Efficacy of denture adhesives in maxillary dentures using gnathodynamometry: a comparative study. Gerodontology. 2011; 99(2): 155-161.

3. ADISMAN, I.K. The use of denture adhesives as an aid to denture treatment. J Prosthe Dent. 1989; 62(6): 711-715.

4. OZCAN, M., KULAK, Y., DE BAAT, C., ARIKAN, A., UCANKALE, M. The effect of a new denture adhesive on bite force until denture dislodgement. J Prosthodont 2005; 14(2):122-126.

5. KORONIS, S., PIZATOS, E., POLYZOIS, G., LAGOUVARDOS, P. Clinical evaluation of three denture cushion adhesives by complete denture wearers. Gerodontology. 2012; 29(2):161-169.

6. SAMPAIO, B, FIGUEIRAL MH, SOUSA RP, FERNANDES MH, SCULLY C. The effect of denture adhesives on Candida albicans growth in vitro. Gerodontology. 2011; 29(2):348-56.

7. DUQUM I, POWERS KA, COOPER L, FELTON D. Denture adhesive use in complete dentures: Clinical recommendations and review of the literature. Gen Dent. 2012 NovDec; 60(6):467-77.

8. GRASSO JE. Denture adhesives. Dent Clin North Am. 2004; 48(3): 721-33.

9. OLIVEIRA, M.C., OLIVEIRA, V.M., VIEIRA, A.C., RAMBOB, I. In vivo assessment of the effect of an adhesive for complete dentures on colonization of Candida species. Gerodontology. 2010; 27(4): 303-307. 